\title{
Islam Re-Observed: Sanctity, Salafism, and Islamism
}

\author{
Lahouari Addi
}

\begin{abstract}
Clifford Geertz analyzed religious change in Morocco by developing an approach to Islam that uses both history and anthropology. His analysis is rooted in his conception of anthropology as a discipline whose focus is culture, a system of meanings through which human beings exchange goods and symbols. In traditional societies, religion has a particular place in this system where it plays a political role of legitimation. European domination provoked change in Morocco, including the decline of sacredness and the triumph of Salafism, a doctrine more appropriate to the national feeling. A postGeertzian perspective might consider that Salafism, which has become an official doctrine of the postcolonial state, became radicalized while it was providing mass education, giving rise to the Islamist challenge. The decline of sanctity created a void that Islamism filled.
\end{abstract}

Keywords: North Africa, Islam, sainthood, Salafism, Islamism, baraka, siba, makhzen, cultural anthropology, symbolism, anthropology of religion, Geertz, ethos, world view, charisma

The December 2007 conference on "Islam Re-Observed: Clifford Geertz in Morocco" was an opportunity for many scholars from various countries to reassess Geertz's approach to the Maghreb in general and to Islam in particular. In his book Islam Observed (1968), Geertz laid the foundations for an anthropology of Islam radically different from the essentialist vision of Orientalism. Geertz is known as an anthropologist of Indonesia and Morocco, countries he studied through the same religion, Islam, which was the main focus of his fieldwork. His theoretical originality lies in his rejection of the analyses of macro-sociology, preferring the microsociological approach which deals with the empirical reality lived by individuals, as opposed to the "total" reality. This epistemological "bias" is 
justified by the fact that only the acts of individuals yield insights on meaning produced by psychological consciousness, which is not produced by collective actors (e.g. lineage, tribe, nation, state). It is from this theoretical point of view that Geertz undertakes the analysis of Morocco as a cultural system in which religion is the language and symbol of the social bond. In this paper, I will first examine Geertz's conception of religion and the features of his anthropology of Islam; then I will illustrate that approach by his analysis of the manifestation of the divine in the social world through the relationship between baraka (sanctity) and state power in Morocco; and finally I will propose a post-Geertzian approach to explain the evolution from Salafism to Islamism. This will justify the title of my paper, "Islam ReObserved," forty years after it was observed in a little book that challenged academic theories of Islam as a religious phenomenon in the process of secularization or an ideological force tamed by Westernized local nationalism.

\section{An Anthropology of Islam}

A specialist in Indonesian and Moroccan "Islams," Geertz gained renown among scholars as an original anthropologist producing an innovative analysis of the religious phenomena he perceived through cultural forms. Influenced by Talcott Parsons, whose student he was at Harvard University, Geertz distinguishes the cultural system (including religion, ideology, common sense, art, science, etc.) from the social and the psychological systems. Culture would be the symbolic outcome of intersubjectivity which constructs the social system in its morphological and objective dimensions. ${ }^{2}$ Society would thus be a community of subjective beings organized in social groups and communicating by means of signs and symbols which make up 
the cultural subsystem. Geertz rejects positivism as ignoring the particularity of social life. His approach stresses cultural transformations from a phenomenological point of view which gives all-importance to world view and meanings. In spite of the importance of culture, Geertz avoids culturalism while insisting on the social bond reproduced by people in their ceaseless interaction marked by communication and the exchange of signs and symbols. If there is one assumption that Geertz refutes, it is that society resembles a machine and that anthropology is the study of its functional logic. Society is neither an engine nor a substance; it is a flux of signs, symbols, and meanings. In order to understand a society, it is necessary to start by observing public places, such as, for example, the zawiyas or the markets, which can provide information about social practices. In this undertaking, Geertz deploys a symbolic approach with an emphasis on meanings, practices, behaviors, and institutions. The social bond is seen in its several aspects related to economy, religion, psychology, etc.

It is within this theoretical framework that Geertz analyzes Islam in Indonesia and Morocco, perceived through the cultural forms of piety. However, he has neither a general theory of society (as Parsons) nor a comprehensive approach to all religions (as Durkheim). On the assumption that science is based on local knowledge, Geertz focused on Islam, a religion that, for at least two centuries, has experienced upheavals and cultural changes that are still under way today. He pays attention to the evolution of cultural forms and hence to history. When Geertz began his research in the 1950s, Islam was not a promising academic topic. Indeed, theorists of modernization and acculturation were then predicting, if not the marginalization of religion, at least its secularization in the new states of the Third World, where triumphant nationalism promised to make up for lost 
time with respect to the West. Against this dominant scholarly trend, Geertz's work on Indonesia showed the syncretism of the local religious phenomenon and the new imported ideology, i.e. nationalism. If he did not reject analyses of the secularization of societies, he was wary of discourses on "the return of religion" which revealed, according to him, a lack of perspicacity on the part of researchers who wrongly supposed that religion had faded away in the new states but was now on the rebound. For Geertz, religion was always there, but the conceptual tools of positivist analysis did not make it possible to see it (see Geertz 2007). Religion is hidden in the syncretism between a faith long rooted in society and a modern ideology that believers adopt in the wake of colonial domination.

In Indonesia Geertz observed that, just as Islam had taken over Hindu civilization by preserving the local way of life, nationalism mobilized Islam by reproducing the natives' ethos. Under the nationalist varnish of the charismatic Indonesian leader Sukarno, the religious spirit persisted in a new language, revealing as much change as permanence. Geertz took an interest in Morocco after having built his reputation as an anthropologist of Indonesia, and in comparison with his writings on the latter, he produced only three works on the former which, it must be said, are of an exceptional density, pioneering a deeper understanding of the political and social significance of Islam in Moroccan society. ${ }^{3}$ In these works, he explains why the Qur'an does not inform us about Muslim societies and why it would be superfluous to say that the attitudes of Muslims conform to the sacred text. Moroccan society, to take this example, "absorbed" the Qur'an and gave birth to Berber Islam, an original sociological phenomenon that must be approached using history, sociology, psychology, political economy, literature, etc. Geertz endeavors to show how Moroccans legitimize their 
ethos by the Qur'anic text, building institutions and imagining a symbolic system that creates social reality. North African or Berber Islam is apprehended through cultural manifestations, and when there is change, it works through institutions and symbols to perpetuate a faith to which the preceding world no longer corresponds. ${ }^{4}$ The change in question occurred once and it benefited Salafism to the detriment of maraboutism.

From the same religion in Morocco and in Indonesia, Geertz outlines a parallel between two experiences that produced different "mystics."

Kalidjaga in classical Morocco would not be heroic but unmanly; Lyusi in classical Java would not be a saint but a boor. (Geertz 1968, 98)

This comparative remark highlights the importance of anthropological structures, including the imaginary which grants certain individuals the resources to affirm their sanctity and thus the potential to be feared. Like everywhere else, the basis of authority is belief, a subjective attitude that confers legitimacy on certain social characters who correspond to the expectations of a given public. Charisma does not depend on personal gifts alone; nevertheless, these gifts must be regarded as such by a public that validates authority on the basis of cultural criteria.

Religion is only part of the symbolic action related to the metaphysical issues and the moral paradox that interest Geertz through ethical considerations. He defines religion as a cultural system that provides believers with the cognitive framework within which the objectivity of the world and the subjectivity of the individual join and abide. Religion is a model that explains the world by giving meaning to the mystery of nature (sun, night, rain, illness, death, etc.). It also expresses of the moral sense of 
the person who seeks to distinguish between good and evil on an external objective basis independent of his own will. Ethos and world view are articulated to build a culture that is reproduced by the practices of individuals, to the point that culture appears to be the expression of reality, and only the mad and the feeble disbelieve the truths it contains.

Faith as a social force and in its symbolic forms is the true object of the anthropology of religion, and it is useful to study transformations of the cultural forms and semiotic expressions of faith in order to understand the social dynamics of countries rent by conflicts whose stakes go beyond religion. One should be attentive to evolutions in the social and cultural expressions of a faith that continues to refer to the same dogma. Scriptural religion does not have the autonomy that positivist Orientalism attributes to it and which would make it a determining factor in social life. Rather, one should consider the reverse: symbolic and institutional religious practices reveal the local anthropological structures. Religiousness exists only through the religious-mindedness that echoes the social imaginary as much as the material conditions of existence. Faith is displayed in rituals and expressed in symbolic forms that correspond to the ethos of a society. The emphasis on symbolism invites us to interpret manifestations of the sacred in its changing forms, e.g. enthusiasm, mysticism, secularized piety, desire for reform, etc.

"How is it," Geertz asks, "that the religious man moves from a troubled perception of experienced disorder to a more or less settled conviction of fundamental order?" $(1973 \mathrm{~b}, 109)$. This question is at the heart of the anthropology of religion, says Geertz, emphasizing that religion comes to people not through simple observation of the tangible world but from a mental operation that implements the idea of authority dwelling in "the persuasive power of traditional imagery" (in tribal religions), or in "the 
apodictic force of the supersensible experience" (in mystical religions), or in "the hypnotic attraction of an extraordinary personality" (in charismatic religions) (110). Geertz attempts to show that faith (in authority) comes not from experience or knowledge; rather, the reverse: "he who would know must first believe" (110). The essence of religious action is "the imbuing of a certain specific complex of symbols - of the metaphysic they formulate and the style of life they recommend - with a persuasive authority" (112). Hence Geertz's definition of religion as

(1) a system of symbols which acts to (2) establish powerful, pervasive, and long-lasting moods and motivations in men by (3) formulating conceptions of a general order of existence and (4) clothing these conceptions with such an aura of factuality that (5) the moods and motivations seem uniquely realistic. (Geertz 1973b, 90)

If religion absolutely must be defined, Geertz would say that it is a cognitive framework that provides an explanation of the world and an ethics that echoes the moral sense. Incorporated as a cultural model, this framework finds psychological resources in the individual's subjectivity to influence his moods, stimulate feelings, and release an energy that seems to be independent of his will. Without confusing psychology with sociology, Geertz delimits the psychological sources of social action by using categories of feeling, motivation, predisposition, passion, etc. Established social values set the norm, and individuals will seek to meet the norm which determines what is true or false, good or evil. They will be motivated by their sense of truth, fairness, beauty, etc. But even if this sense is intimate, it is generated by the symbolic environment. Completion of a religious 
obligation, prayer in a sacred place, participation in a collective ritual, etc., give a sense of duty accomplished and thus observance of morality, order, reason, or, on the contrary, a sense of having failed, of not meeting expectations.

This analytical approach to religion involves three levels: 1) the psychological (dispositions, feelings, motivations, passions) being deeply influenced by 2) the cognitive framework (the causal explanation of surrounding reality) with the facilitation of 3) symbolic forms that make the world familiar and human. Up to the time when he was writing in the 1960s, anthropology had neglected the third level, according to Geertz, which he considers the most important for understanding religious phenomena. ${ }^{5} \mathrm{He}$ emphasizes the interweaving between religion and what is called society to such an extent that one might wonder which of the two categories is the object of his study. ${ }^{6}$ Through the study and analysis of religious practices, the researcher realizes that society is less an organic reality than a flux of multiple interactions conveying goods and services but also words, images, and symbols expressing an ethos and a world view that make sense "from the native's point of view." The concepts of ethos and world view are important in Geertz's approach; he devoted an article to them in 1957 (repr. in 1973a) and would use them constantly in his later work. He acknowledges that they are not precise concepts, referring to moral and aesthetic aspects for the first and cognitive aspects for the second:

A people's ethos is the tone, character, and quality of their life, its moral and aesthetic style and mood; it is the underlying attitude toward themselves and their world that life reflects. Their world view is their picture of the way things in sheer actuality are, their concept of nature, of 
self, of society. It contains their most comprehensive ideas of order. (Geertz 1973a, 127)

Ethos and world view combine and appear in symbolic form through narration, ritual, behavior, and other actions to form a collective style of life. It is thus, says Geertz, that "religious symbols formulate a basic congruence between a particular style of life and a specific (if, most often, implicit) metaphysic, and in so doing sustain each with the borrowed authority of the other" $(1973 \mathrm{~b}, 90)$. Although this approach is not new, he adds, it has not been sufficiently investigated to demonstrate empirically how "this miracle" occurs. This was the task he set for himself in undertaking fieldwork in Indonesia and Morocco, on the basis of which he developed an anthropology of religion that pays more attention to culture and the problems of interpretation. He insists on the role of symbols as the positive content of any cultural activity, while trying to avoid the pitfalls of introspective psychology and speculative philosophy. He seeks to establish an empirical basis for this symbolic world which sociologists have attempted to explain by considerations of logic. ${ }^{7}$ Nurtured by but not reduced to common sense (which was where Malinowski went wrong; Geertz 1968, 92-3), religion is an intellectual construction whose field exceeds the everyday world. It mobilizes superhuman characters and monsters from the social imaginary that express the sensitivity, the emotions, and the hopes of individuals in search of themselves.

What Geertz found is that ethos and world vision contain religion and emerge from the local anthropological structure. That is why Moroccan Islam is different from Indonesian Islam, just as French Catholicism is different from Mexican Catholicism. Geertz seems to be saying that 
scriptural religion is not as univocal as theology says it is, because lived religion is borne by a civilization or by "the spirit of a people" which clothes it in its own ethos. "It is really not much easier to conceive of Christianity without Gregory than without Jesus. Or if that remark seems tendentious (which it is not), then Islam without the Ulema than without Muhammed" (Geertz 1968, 3). For Geertz, the problem is "not to define religion but to find it" (1). Religion is not only transcendence or mystical manifestation, it is above all a cultural system enveloping a society. Culture contains social activity by giving meaning to the various acts of individuals. Geertz applied this approach to Morocco via Islam, a window that opens onto Moroccan society in all its sociological complexity and historical depth.

\section{Sanctity, Baraka and State Power}

Geertz left his mark on the sociology of religion with his study of Islam in Indonesia and Morocco. His seminal article, "Religion as a Cultural System" (1966, repr. in 1973b) has often been cited by subsequent generations of scholars of religion. He put forward the idea that religion is the fusion of an ethos and a world view, and that so-called religious crises occur when these two categories no longer correspond. In addition to being a source of knowledge, religion is the source of legitimacy for political authority in nonsecular societies, hence its importance for the ruling elite. It dictates what is legitimate and indicates who shall be the Prince whose mission is to ensure fairness.

Geertz asks what made a peasant from the Atlas Mountains like Sidi Lahcen Lyusi, who had neither money nor troops, defy the powerful Sultan Mulay Ismail, whose legendary cruelty has been reported by historians. What made the ruler recognize this tribal man's prerogative, strength, and 
grace and prevented him from arresting the man and torturing him as he did with his foes? It was sanctity, Geertz answers, the belief in sanctity as a moral force endowed with the power to bless or to curse.

Islam in Barbary was - and to a fair extent still is - basically the Islam of saint worship and moral severity, magical power and aggressive piety, and this was for all practical purposes as true in the alleys of $\mathrm{Fez}$ and Marrakech as in the expanses of the Atlas or the Sahara. (Geertz 1968, 9)

This is the first assumption - verifiable on the ground and in history - on the basis of which Geertz undertakes to understand the Moroccan socioreligious milieu, which is quite different from that in Indonesia. ${ }^{8}$ The attribute of sanctity is baraka, the mana of the Berber people that causes life to reproduce and people to be disciplined and obey the rules, thus averting disorder (fitna). Baraka is "a conception of the mode in which the divine reaches into the world. Implicit, uncriticized, and far from systematic, it too is a "doctrine"" (1968, 44, my emphasis). It is above all a symbolic construction that orders the social hierarchy, at the top of which are those who are endowed with it and thereby designated by God to wield the authority over the people.

Baraka is a formidable resource: "the problem is to decide who (not only, as we shall see, among the living, but also among the dead) has it, how much, and how to benefit from it" (Geertz 1968, 44). Geertz analyzes baraka through those who are endowed with it and those who respect it. Baraka is an essential component of the political system; it creates micropowers that sometimes serve as counterweights to the central power and sometimes as intermediaries between the sultan and the believers. Baraka corresponds to 
Max Weber's definition of charisma, in that it makes obedience possible without the use of the physical force. ${ }^{9}$ He who has baraka has the gift of transforming the social environment, releasing an energy that exalts the crowd. It is related to the phenomenon of the sacred as manifested in the Durkheimian mana that provokes social effervescence. The individual who has baraka, i.e. the saint, attracts and crystallizes in his own person the religious feelings of the group for whom he is the symbol, the totem. "Moroccan maraboutism portrays reality as a field of spiritual energies nucleating in the persons of individual men, and it projects a style of life celebrating moral passion" $(1968,98)$.

Externalized, the feelings of several thousand people are projected onto the saint who now possesses a strength that confirms his charisma. Baraka is symbolic capital whose value is measured by the numbers of the faithful and their capacity to venerate the symbol through which they exalt their membership in their respective groups. Baraka is not a psychological quality inherent in the person of the leader but the social construction of a group united around its own forms of the sacred. Saints do not impose themselves; they are produced by the social environment wherein the symbolic order that provides meanings and social hierarchies finds its justification in Islam. Sainthood is the expression of an ambient religiosity characterized by fervor and devotion; it is a cultural and psychological phenomenon that surpasses religion itself, i.e. ritual practice. The most important feature of this mechanism is the process of social validation whereby certain functions are validated and others discounted.

Sanctity in the Maghreb is as much a religious phenomenon as it is a political resource. It takes baraka, divine grace, to lead people or run a state. Baraka is decisive in the political struggle, since it legitimizes authority. 
Baraka is necessary to the construction of hierarchy in societies where genealogical ethnocentrism - whence the generalized sense of honor makes everyone believe he is of a higher lineage than others. While honor is relatively abundant, since practically every man is equipped with it, baraka is a scarce resource. From this point of view, baraka prevents the social system from sinking into anarchy brought on by the competition of lineages. But when baraka is abundant, it too becomes a source of anarchy. An excess of vectors of authority kills authority; relative scarcity enhances it. Historians have noticed that periods of political instability correspond to a maraboutic plethora, or what Jacques Berque calls "the maraboutic revolution."

Sanctity is hereditary (through genealogy), but one can also become a saint provided that evidence is shown. Geertz distinguishes two sources of baraka: on the one hand, the performance of miracles or the possession of knowledge, and on the other, assumed prophetic ascendancy. Maraboutism in Morocco, says Geertz, prevented sanctity from being the monopoly of the reigning dynasty. The king is a saint because he is sharif, related to the Prophet, but he is not the only one with the status of sainthood. Some of his subjects can acquire personal charisma themselves. In the competition between these two principles (the institutional and the popular) lies the secret of the tensions that mark the history of Morocco. Through this competition, popular and miraculous phenomena contest the reigning dynasty's monopoly on authority and sanctity, to some extent setting up a counterweight to the monarch. Hagiographic narrations recount how entrenched marabouts defied the monarch and accused him of failing his commitments to the believers or to God. These narrations express the dissatisfaction of people who complain of unjust rulers and find in the 
audacious marabout the defender of social justice (' $a d l$ ) as set forth in the Islamic imaginary. The sociopolitical system thus has two legitimacies: one, institutional, centered around the person of the king as a descendant of the prophetic line and thus inherent in state power; the other, emanating from the popular Islam of towns and rural areas, conveyed and disseminated by those endowed with a personal charisma that makes them the agents of divine order. The history of Morocco, at least until the nineteenth century, was tied to the ceaseless struggle between these two legitimacies which nevertheless attract more than reject each other.

Tension between the prince and the marabout is not the rule. Geertz speaks of "capitulation in the guise of rebellion - the sherifian principle of religious legitimacy accepted in the course of a moral collision with its quintessential representative - [as] superbly diagnostic" (Geertz 1968, 48). He also evokes the unification of the two principles operated by Sufism whose function is to bring "orthodox Islam (itself no seamless unity) into effective relationship with the world, rendering it accessible to its adherents and its adherents accessible to it" (48). Sufism would thus adapt the revelation contained in the Qur'an to the local ethos by producing multiple and various experiences that help to understand the stakes in North African political history. Moroccan Sufism "meant fusing the genealogical conception of sanctity with the miraculous" (48). More importantly, the entire system - in its politico-religious aspect - is structured by Sufism through three institutions whose peaceful relationships guarantee stability: the local saint incarnated in a tomb surrounded the fervor of a cult whose intensity matches the saint's fame; the zawiya, the seat of a brotherhood, a religious organization that often crosses tribal boundaries and is capable of calling up thousands ready to answer the leader's call; and finally, state 
power, known as makhzen, an institution that relies on sainthood and brotherhood to guarantee its existence. These three institutions all have baraka in common, which gives them coherence and relevance and the ability to turn religious conviction into social energy, whereby any one of the three can impose its hegemony over the others, or they may balance their relative powers with perhaps one of them scrambling for position. But Geertz tends to emphasize the unity of the system over its divisions and conflicts. "Popular saint worship, sufist doctrine (both Spanish and Middle Eastern), and the sherifian principle all flowed together, like a swelling stream, into a single precut spiritual channel: maraboutism" (54).

In the course of several pages in his essay on "Centers, Kings, and Charisma," Geertz outlines the rationale of Morocco's political order prior to colonization, with movement and energy (haraka and baraka) as its two salient features (Geertz 1983, 134-42). If the king, he explains, were to remain holed up in his palace, he would lose authority over the country because of his charismatic competitors and the potential spread of siba (lit., insolence). The makhzen must be ever on the move, demonstrating the symbolic system of state power, in order to neutralize rebellious tribes and contain them within geographical limits (mountains and deserts). The sultan moves with his court, his army, and his loyal tribes, which means that the capital, the locus of state power, is itinerant. This explains why Morocco has several royal cities: Rabat, Fez, Meknes, and Marrakesh. The sultan must move about in a country where the political units (tribes) are also constantly on the move, which implies modifications of loyalty and allegiance, since the siba will often find religious leaders whose charisma is devastating for the reigning authority. ${ }^{10}$ The tribal phenomenon imposes mobility on state power because the stake is not land - as a source of wealth - but power and 
influence embodied in institutions. More than elsewhere, the instrument used to dominate people is a collective belief whose expression - baraka - is the fundamental stake in the social system. Hence the importance of religious beliefs, without which the system would collapse, because in order to sustain itself, it requires loyalty through which physical force is recruited to military ends. Supremacy comes not from economic property; rather, it is an effect of baraka. People - with their material wealth - lend allegiance to whomever possesses it. Having wealth is itself a sign of baraka in a system where strength is a source of wealth according to the logic of predation.

To protect his throne from constant military and religious defiance, the sultan must show that his baraka is stronger by demonstrating his strength and challenging potential competitors in their own locations. Moving 30,000 to 50,000 people, i.e. organizing life in an itinerant city, is itself evidence of energy and power. This is the aim of the mehalla (waystation, camp), during which allegiances are pledged and taxes collected. The political struggle is not for control of geographical positions or economic centers; rather, it is for control of strategic axes, the subjection of space, and the acquisition of loyalties.

If Moroccan society has any chief guiding principle, it is probably that one genuinely possesses only what one has the ability to defend, whether it be land, water, women, trade partners, or personal authority: whatever magic a king had he had strenuously to protect. (Geertz 1983, 136)

No matter what you have, you must defend it, otherwise it will be taken from you. Having that which makes it possible to have anything else, i.e. power, the sultan is more exposed than anyone. In this context, material 
wealth is not the foundation of power, rather, it rewards and follows power. Strength and loyalty are the basis of power, whence the culture of la parole donnée, a man's word, which does not exclude personal ambitions, provided one is confident in the possession of his resources - including baraka because nothing is worse than failing in a rebellion against the leader to whom one has pledged one's loyalty. Political relationships are shaped by the balance of power and they respond to force. Machiavelli acts and the saint justifies.

The sultan's power is a sign of grace; it means that he has baraka, the means of divine presence on earth, first of all through rituals, but also in providing assistance to orphans, the needy and the poor, etc. Power fascinates the masses; they fear and respect the sultan (hibat ed-dawla) who seems to be closer to the divine than to the temporal order. Others who possess baraka covet the fascination of the majority; those who think they have sufficient legitimacy to lead are tempted to venture the conquest of this mystical object. Hence the dialectic of submission and rebellion that characterizes the history of North Africa. The most dangerous protagonists in this competition are the idealists who make power an instrument to realize the divine will, usually through the stricter application of religious norms which they believe the sultan has unjustly ignored. These contenders are the most tenacious, the least inclined to compromise, the least tempted by gifts. They are prepared to die for their ideal, and this gives them the strength to defy authority until they are militarily defeated or they achieve their goal. For all of these reasons - materialistic and idealistic - state power remains on the defensive, facing perpetual defiance in a social context where strength is the only reliable political resource. Hence the predatory character of state power which, in order to increase its military strength, must levy tribute 
from the tribes. The nature of the political struggle is such that the political interests of state power take precedence over wealth, and that the latter proceeds from the former. ${ }^{11}$

This model entered a crisis in the nineteenth century and with the advent of colonial domination it ceased to exist, out of which, indirectly, a modern form of nationalism was born. The Protectorate and the struggle for independence allowed the reigning dynasty to dominate its traditional adversaries and make them know that their loyal service was expected. The dynasty benefited from modernity in terms of administration, police, army, and radio and television which it used to serve its own interest, that is, to endure whatever the circumstances. Formerly, saints and brotherhoods were areas of autonomy in relation to the makhzen, opposing it on occasion, integrating and reinvorgating the social system by their very opposition. ${ }^{12}$ Basically, the Moroccan political system changed as a result of a shift in the balance of power in the religious arena.

Geertz interprets the aftermath of the North African Nahda (awakening, renaissance) - its emblematic figure in Morocco was 'Allal alFasi - as an anti-Sufi reaction that reinforced the monarchy in the face of European domination. The energy of religious fervor was rationalized, disciplined, mobilized to support the sultan in the struggle for independence. In this case, the ulema had a greater political role than in the past, campaigning against the so-called maraboutic jahiliya (ignorance) in order to steer religious loyalty toward the sultan, henceforward the incarnation of the nation. Now the sultan would only rarely avert to his brotherhood and maraboutic connections. Thence forward he would refer to Salafism, the doctrine upheld by the kingdom's ulema. Thus the makhzen took advantage of modernity to marginalize both the saints and the brotherhoods. It was one 
of the most significant political changes that took place in Morocco under the colonial order.

Medieval Morocco produced saints; contemporary Morocco does not. If Islam is as present now as it was in the past, Geertz asks, what changed? His anthropology allows us to see the adaptations of the imaginary and the symbolic order as maraboutism was supplanted by the Salafi doctrine that would provide the discourse that legitimizes authority. Symbolic forms of piety altered as the balance of power shifted among religious institutions.

Geertz was interested in the evolution of the imaginary and the symbolic order related to lived religion which serves as the cognitive framework for the legitimation of authority on which the political system rests. He shed light on a process that also drew Ernest Gellner's interest (1981), which was the decline of maraboutism and the rise of Salafism, whose hegemony is related to Western domination and the formation of the nation-state. On this socio-anthropological basis, Geertz pursued the question of how to understand the dynamics of change in Moroccan society. More important than observing the effects of contact with the West, for Geertz, was his analysis of the processes by which change took place, for, as he concludes, it was no longer the same society.

What we want to know is, again, by what mechanisms and from what causes these extraordinary transformations have taken place. And for this we need to train our primary attention neither on indices, stages, traits, nor trends, but on processes, on the way in which things stop being what they are and become instead something else. (Geertz 1968, 59)

Geertz suggests that religiosity significantly weakened but the 
religious spirit was still there. Certainly the sacred text hadn't changed, nor was the change a matter of faith; it was the practice of lived religion that changed, its social institutions and its rituals. Now the question was not "What shall I believe?" but "How shall I believe it?" (Geertz 1968, 61). Doubt did not undermine faith; it gripped the believers themselves; their world view no longer corresponded to reality. Had God abandoned his creatures? Would the world survive the fourteenth century AH? Piety remained, Geertz observes, but not confidence. "How do men of religious sensibility react when the machinery of faith begins to wear out? What do they do when traditions falter?" $(1968,3)$. The change offered North African societies a choice between utopia and millenarianism or disenchantment and historical consciousness. The Maghreb took the middle course, mixing millenarianism and historical consciousness, giving birth to a nationalism that was modern in form and ancient in content. Influenced by Salafism, it was the vehicle for a utopian ideal that reproduced the myth of the state overseeing fairness and happiness. In spite of its archaisms, North African society grew disenchanted with maraboutism. The surviving brotherhoods and zawiyas no longer have the influence they had in centuries past. The bouniyya (naïve believer) whom Bourdieu discussed in the context of Kabylia no longer exists in Algeria or Morocco.

In this context, it is not surprising that the sultan of Morocco, of maraboutic origin though he was, made common cause with the Salafi movement and entrusted the ulema with the defense the postcolonial state's interpretation of Islam. Popular religion as manifested in sainthood, musems, zawiyas, etc., lost its strength during the colonial period and continued to decline after independence under pressure from social, economic, and cultural changes such as rural migration, generalized monetary exchange, 
and the decline of traditional educational institutions. Social changes wrought by wage-earning and commercial exchange led to urban individualism and helped weaken the traditional religiosity that corresponded to the communal way of life (see Addi 1999). This sociological approach highlights the increasing lack of coherence between maraboutic culture and the social system. Cultural cohesion was disrupted by historical changes. Individuals began to doubt themselves and wonder whether they had changed the religious message, from which arose the utopian dream of going back to the source by imitating the model of the pious ancestors (al-salaf al-salih), and being loyal to the sacred text. Scriptural Islam, Salafi Islam, took advantage of these developments. Devoid of individual or collective ecstasy, corresponding to new social and political aspirations inspired by colonial domination, it successfully challenged the Sufi heritage.

\section{From Salafism to Islamism}

This is the historical and conceptual framework within which Geertz approaches religious change in Muslim societies. He asserts that researchers have not taken the measure of the chasm that divides a world view, with its cultural and sociological relevance, from Western domination which denies that relevance. The traditional Muslim imaginary was full of signs and meanings that confirmed the logical structure of the world. Social reality was built, or rather perceived and lived, beneath the gaze of the divine mediated by the ulema and the saints. Unfortunately, or fortunately, that world disappeared and the signs became orphans. Traditional Islam, quietist and maraboutic, saw the Ottoman Empire collapse and was itself impotent in the face of military defeat by Europeans whose new God was science and 
technology. The new reality shattered the psychosocial equilibrium of common sense which could neither comprehend nor admit the superiority of Europe. Why had the powerful saints failed to protect Dar al-Islam from European domination? Neither the saints with their omnipresent and deterrent baraka, nor the ulema with the secrets of divine power in their possession could prevent this unnatural (from the believers' point of view) supremacy. Their symbolic system could no longer influence reality. Reality was detached from the symbol that had made sense of it. It was like an earthquake, says Geertz; the psychological and sociological consequences introduced doubt into a culture that until then had been confident of its validity and its cosmological superiority. Believers wondered whether they were worthy of the faith, since they were convinced that their religion is the best and the Qur'an is the word of God. They felt guilty and questioned their traditional way of believing, and this caused profound religious changes, the most spectacular being the near disappearance of maraboutism and the brotherhoods. Scripturalism stepped forward to reconstruct the symbols and sustain the religious spirit by going back to the source, to the pious ancestors whose message had been distorted through centuries of wrong practice.

But the scriptural Islam propagated by Salafism is not secularization. Rather, it signals the end of popular religiosity and religious bigotry and ensures the hegemony of religion over all social activities. Salafism turned Islam into an ideology in order to protect it from encroaching modernity, which is why it is not the equivalent of the Protestant reform that set in motion the dynamic of secularization in Europe. Scripturalism or Salafism had nothing to do with the content of faith; if it had, there would have been a profound religious revolution, likely producing a schism as in Christendom. Islam experienced institutional but not dogmatic change. There was no new 
interpretation of the sacred text. The ideologization of Islam tells us about the disarticulation of religious symbols from social reality. There was no Luther amongst the Muslims; there was no Weber amongst the specialists in Islam. This is where Geertz departs radically from Gellner who considered Salafism to be the source of modernity.

Salafism was certainly a nationalist reaction to European expansion, but its analysis and teachings did not break with the myth of origins. Its explanation of the Muslim predicament was, briefly, as follows: 1) Muslim society is dominated by Christendom because it has become weak; 2) it is weak because it has drifted away from original Islam; 3) it is necessary to return to the origins and root out influences posterior to the pious ancestors, including maraboutism, a pagan Berber relic; 4) maraboutism prevents the establishment of a central authority that can embody the nation and organize the struggle against colonial domination.

After prolonged resistance to colonial domination, Salafism finally had its state, but did it meet the needs of modernity? Did it create a new world view to liberate the temporal from the tyranny of the sacred imaginary? Thanks to mass education, the Salafi discourse is no longer reserved for the elite. It has been popularized and has reached the poor urban classes who now use it to denounce the government's failure to end poverty, social inequality, corruption, and so forth. By winning over the popular classes, the Salafi discourse gave rise to Islamism among the new educated generations and now they threaten the regime. And the authorities are encouraging the brotherhoods against the Islamists whose defiance of the monarchy has made them popular.

A few years after independence, Salafism became radicalized as it evolved into political Islam, sometimes using violence to protect the faith. 
Salafism had the political-ideological answer to the colonial situation - the creation of an independent state - but it has no answer for the postcolonial situation in terms of a modern political project (democracy, the rule of law, separation of powers, etc.). Its historical relevance stems from the fact that it corresponded to the patriotic expectations of the peoples who rejected colonial domination. Those same patriotic expectations remain, while the economic and social development gap vis-à-vis the West has widened. Social unrest is fuelled by disappointment and the feeling that the nationstate has been "monopolized by elites who betrayed the ideal of the national struggle and became the relay for Western economic and cultural domination." This is the creed of the Islamist movement which claims the Salafi heritage and promises "true liberation." Contemporary Islamism is a post-independence Salafism or neo-Salafism that seeks to achieve liberation by entrusting direction of the state to "true" Muslims whose faith brings them closer to the masses, now forsaken by "a corrupt elite turned toward the West."

In this sense, Islamism predates the independence of the Maghrebi states; its ideology was already developed by Jamal al-Din al-Afghani, Muhammad Abduh, Rashid Rida, and their disciple Hasan al-Banna. The continuity between contemporary Islamism and Salafism is obvious: education was turned over to the Salafis (it could not have been otherwise) and they formed generations who believe in the historicity and perfection of the model of the pious ancestors. For Geertz, "rather than the first stages of Islam's reformation, scripturalism in this century has come, in both Indonesia and Morocco, to represent the last stages in its ideologization" (1968, 69-70). What is called "Muslim reformism" - the ideologization of scriptural Islam, the rejection of post-Qur'anic commentaries, the 
mythologization of the pious ancestors - did not aim to build a new sociopolitical order but rather to defend the old order by adapting the faith to the new political framework. i.e. the nation-state. This provoked significant change but not deep enough to release an internal dynamic of modernity. Scriptural Islam was not strong enough to build a symbolic system compatible with modernity, as Protestantism did in northern European societies at the beginning of the modern era.

Salafi reformism had two aims: to liberate the country from colonial domination and to modernize society. It succeeded in the first but failed in the second because it denied the historicity of Muslim society which it confines to a mythical past. Salafism prevented common sense (in the Geertzian sense) from accepting the profane knowledge that could have neutralized the myth and the tyranny of the sacred. Of course, a century passed between Jamal al-Din al-Afghani and independence in the Maghreb, and men are marked by the historical processes that produce them as well as by the ideas they defend. 'Allal al-Fasi, who died in 1974, was a Salafi who was very open on many social issues. But then a characteristic of ideological movements is to embrace trends ranging from the most moderate to the most dogmatic.

In the end, social expectations remain the same, i.e. modernization and social justice, and they have not been realized by the independent state. Educated in the Salafi school, the Islamists propose to meet these expectations by going back to the model of the Prophet's generation. A great deal has been written about Islamist movements, but this much is certain: they are a contradictory expression of modernity in societies under cultural and economic domination. They are mechanically modern in the sense that they make it possible for the popular classes to be heard in the political 
arena, but they are ideologically conservative insofar as they apply morality and psychology to political problems (see Addi 1997). The failure of the North African state is basically that of Salafism which was its ideological touchstone and whose principal weakness is that it granted too much importance to the Muslim's cultural identity, to the detriment of his universality. In its discourse and its implicit assumptions, culture is an ahistorical essence that denies the universal anthropological character of the Muslim individual. Cut off from his humanity, he is entirely absorbed by his religious identity which speaks in his name.

As a result, Muslims are forbidden to imagine a new social and political order, which is likened to bid ' $a$ (innovation). Deprived of historical consciousness, they are immured in rejection and negation. This posture was effective in the national struggle but it produced illusions (stronger in Algeria than elsewhere), and has now become an obstacle to the implementation of the rule of law. Salafism did not encourage the social sciences (sociology, anthropology, history, political economy, linguistics, psychology, political science, etc.) which it suspected of being Western ideologies meant to subvert the Muslim mind. Salafism encouraged Muslims to study the natural sciences (physics, mathematics, biology, etc.) and discouraged them from studying the social sciences. The social turmoil constantly reported in the media points to the need either for the old world, or for a new world to be created by internal forces. Salafism and its byproduct, Islamism, are prisoners of the medieval paradigm that subjects the temporal to the spiritual life. Both express a will to protect the faith in a world where the traditional world view is no longer corroborated by experience. The historical and theoretical weakness of Islamism lies in the desperate will to protect the faith by political means, instead of using ijtihad 
to reinterpret its dogma and adapt it to the new historical reality. This failure to articulate the signifier with the signified explains the violence and the passion of Islamism.

Neither Salafism nor Islamism has been able to invent modern forms of religiousness that correspond to religious-mindedness. As a Kantian anthropologist, Geertz distinguishes between the two concepts which relate to two different realities: social practice (religiousness) and the moral ideal (religious-mindedness). The former performs the latter through rituals. Religiousness is thus the social demonstration of religious-mindedness, giving rise to cults and institutions. The Durkheimian totem captures this social energy and crystallizes it in a symbolic system which eventually becomes detached from religious-mindedness and obeys its own dynamics. Distinguishing between religiousness and religious-mindedness, Geertz is more Durkheimian than he might think, even if Durkheim was primarily concerned with religiousness as a social fact. Durkheim was less interested in religious-mindedness which, according to him, is linked to subjectivity and therefore related to psychology. He was interested in religiousness which, according to him, symbolically reinvents the idealized society as the divinized society. For Durkheim, God is society and vice versa. ${ }^{13}$ This Kantian perspective leads to two conclusions: first, that religion is unavoidable, even if its cultural forms - collective representations - change over time; secondly, new representations for religious-mindedness must be found in modernity. Geertz's paradigm explains the crisis in Muslim societies by the break between religious-mindedness and religiousness. The saints lost their influence in the detribalized rural world, while the ulema no longer have their former prestige. A feeling of collective guilt has been aroused that will persist until religious-mindedness finds new forms of 
religiousness.

In conclusion, re-observing Islam forty years after it was observed by Geertz, we realize that the crisis of North African societies is profound because it is related to the underpinnings of the social bond in its ethical aspect. The ethos, in relation to the individual's moral sense, is expressed and crystallized in the cultural forms of religiousness. In Muslim societies, the moral sense is in search of a new ethnocentrism, insofar as the traditional ethnocentrism lost its substance through contact with the West. Independence promised to restore it in a kind of syncretism of Islam and modernity, but in fact the elites failed to invent a new culture. No social group can live without a proper ethnocentrism. Islamism is a defensive reaction to the failure of the postcolonial state to create a modern culture appropriate to religiousness. Geertz perceived these problems in the 1960 s when he wrote Islam Observed. Forty years later, he would write that he sensed rain then; now we may have gotten a flood (Geertz 2005, 10).

Translation by Lahouari Addi and Diane James

Lahouari Addi is Professor of Sociology at the Institut d'Études Politiques de Lyon, University of Lyon 2. He teaches sociology of the Middle East and North African politics. He is a member of Triangle, UMR-CNRS 5206. He has published numerous books and articles in French and in English. His most recent book is Sociologie et anthropologie chez Pierre Bourdieu: Le paradigme anthropologique kabyle et ses conséquences théoriques (2002). His next book is a comparative study of Ernest Gellner and Clifford Geertz.

\section{References}

Addi, Lahouari. 1997. Political Islam and Democracy: The Case of Algeria. In: in Axel Hadenius, ed. Democracy's Victory and Crisis. Cambridge, UK: Cambridge University Press, 105-20.

Addi, Lahouari. 1999. Les mutations de la société algérienne: Famille et lien social dans 
l'Algérie contemporaine. Paris: La Découverte.

Geertz, Clifford. 1968. Islam Observed: Religious Development in Morocco and Indonesia. New Haven: Yale University Press.

Geertz, Clifford. 1973a. Ethos, World View, and the Analysis of Sacred Symbols. In: Geertz. The Interpretation of Cultures. New York: Basic Books, 126-41.

Geertz, Clifford. 1973b. Religion As a Cultural System. In: Geertz. The Interpretation of Cultures. New York: Basic Books, 87-125.

Geertz, Clifford. 1979. Suq: The Bazaar Economy in Sefrou. In: Clifford Geertz, Hildred Geertz, and Lawrence Rosen. Meaning and Order in Moroccan Society: Three Essays in Cultural Analysis. Cambridge, UK: Cambridge University Press, 123313.

Geertz, Clifford. 1983. Centers, Kings, and Charisma: Reflections on the Symbolics of Power. In: Geertz. Local Knowledge: Further Essays in Interpretive Anthropology. New York: Basic Books, 121-46.

Geertz, Clifford. 2005. Shifting Aims, Moving Targets: On the Anthropology of Religion. Journal of the Royal Anthropological Institute, 11 (1), 1-15.

Geertz, Clifford. 2007. La religion, sujet d'avenir. In: Michel Wieviorka, ed. Les sciences sociales en mutation. Auxerre: Sciences Humaines, 427-34.

Gellner, Ernest. 1981. Muslim Society. Cambridge, UK: Cambridge University Press.

Segal, Robert A. 1988, Interpreting and Explaining Religion: Geertz and Durkheim. Soundings, 71, 29-52.

Segal, Robert A. 1999. Weber and Geertz on the Meaning of Religion. Religion, 29 (1), $61-71$

\section{Notes}

${ }^{1}$ For Geertz, religions are different even when they refer to the same dogma. Thus there are several "Islams," as there are several "Christianities," according to time and place. 
${ }^{2}$ The concept of culture is crucial for Geertz, who divides it into subsystems: religion, art, science, common sense, ideology, etc. In secular societies, ideology becomes the basis for legitimating political power, a role formerly served by religion. Ideology acts as a state religion in countries where religious practices tend to be confined to the private sphere.

${ }^{3}$ Islam Observed (1968), in which his remarks on Indonesia occupy as much space as those on Morocco; "Suq: The Bazaar Economy in Sefrou" (1979); and a chapter titled "Centers, Kings, and Charisma: Reflections on the Symbolics of Power" (1983), in which he compares the Moroccan and the English monarchies.

${ }^{4}$ Heretofore accustomed to studying the atemporal structures of "dead and dying societies," anthropology now needs history, art, literature, psychology, etc., to study these transformations with the aid of documents and manuscripts that are as useful as field research. Geertz was one of the first to reconcile anthropology and history, breaking with the structuralist perspective on the identical reproduction of social systems which the ethnocentrist gaze had fixed in time.

${ }^{5}$ Since the origin of what we call "the science of religions" with Muller in the nineteenth century, it has been difficult to find a definition acceptable to all. Every definition proposed has been criticized for essentialism, sociological or psychological reductivism, or ethnocentrism. We must acknowledge that it is difficult to define a social fact as total as religion. Authors such as Durkheim and Weber gave up on providing a definition, even though their approaches contain implicit definitions of religion; likewise Geertz who presents religion as a cultural system with its own structure of meaning. 
${ }^{6}$ Society in the Durkheimian sense does not exist for Geertz who, like Bourdieu, prefers to reflect on the articulated practices that construct what ordinary language calls society. But it is important to note that for Geertz, it is the analysis of a practice artificially isolated for methodological purposes - that provides information on the logic of the social arena. The social world is an ocean, and chemical analysis of a single drop of water reveals the molecular structure of all the water in the ocean.

${ }^{7}$ For Geertz, religion is a dense and total phenomenon that envelops man in his social being and subjective complexity, implicating social institutions as much as consciousness. The anthropologist leaves the believer's existential anguish to the psychoanalyst or the psychologist, limiting himself to lived religion and the meaning borne by its cults. This restrictive approach draws its theoretical legitimacy from the capacity of institutions, activities, and social forces linked to faith to crystallize themselves and become autonomous from scripture or dogma.

${ }^{8}$ The sacred takes different forms of expression in Indonesia where wet rice cultivation occupies the sedentary peasant, "nursing his terrace, placating his neighbors, and feeding his superiors" (Geertz 1968,11). Islam is manifested in a quietude that is the opposite of the maraboutic restlessness of the Maghreb. The symbolic framework and the imaginary are intimately articulated with the physical space in which a society materially reproduces itself. Hence the variation in the forms of expression of the sacred which frees the energies, called illuminism in Indonesia and maraboutism in Morocco, and which structures power relationships in the socioreligious arena that are manifested at the political level as the energy is captured by certain individuals and transformed into the 
legitimacy that gives authority and power.

${ }^{9}$ Geertz claims to draw inspiration from Max Weber in addressing the problem of the meaning that individuals give to their actions, but he is closer than he admits to Durkheim, for whom society projects itself onto the terrain of religion and vice versa. For Geertz, society and religion are inseparable, one merging into the other, or rather both dissolving into culture to form a system. Sociologists of religion are wrong to cast Durkheim and Weber in opposition, since their approaches converge despite their profound differences. Geertz's reflections on baraka offer an example of this convergence (see also Segal 1988; 1999).

${ }^{10}$ It happens that during their lifetimes such leaders founded brotherhoods which the central power is obliged to deal with because of their ability to mobilize human and material resources into a formidable political force. When they felt sufficiently powerful, these brotherhoods would often attempt to conquer power, and when successful, they would fuse the two principles of legitimacy, making the founder's baraka a family patrimony that could be transmitted from generation to generation, at least insofar as his descendents were able to maintain its vigor and resist the competitors who would certainly arise.

${ }^{11}$ There is a trail to follow here that could provide one explanation - among others - for the freezing of economic development in the Maghreb. The preeminence of political power over material wealth prevents competing dynamics from producing goods. Yesterday the danger arose from religious power which it was necessary to monopolize; today the danger arises from economic power which must not be allowed to 
become a strong political actor who will demand the institutionalization of power.

${ }^{12}$ Supposedly guaranteed by the parties and the unions, political participation is superficial because the state desires to restrain it and distract people from the real game: the competition for power.

${ }^{13}$ In France, these new representations are the values that form the basis for secularism, the civil religion of a disenchanted, industrialized, urbanized society. It was no fluke that Durkheim became the first theorist of secularism as civil religion in France. 